\title{
ADSORPTION OF COPPER IN EXPANDED VERMICULITE: KINETICS AND EQUILIBRIUM
}

\author{
E. NISHIKAWA ${ }^{1}$, A. F. ALMEIDA NETO ${ }^{1}$, M. G. A. VIEIRA ${ }^{1}$ \\ ${ }^{1}$ State University of Campinas, Chemical Engineering School \\ E-mail: ambrosio@feq.unicamp.br,melissagav@feq.unicamp.br
}

\begin{abstract}
The aim of this work was to evaluate copper adsorption on expanded vermiculite through kinetic and equilibrium studies. The kinetics of adsorption of copper into vermiculite was assessed by kinetic phenomenological models of pseudofirst order, pseudo-second-order and intra-particle diffusion models as well as a mass transfer model in the external film. Langmuir, Freundlich and Dubinin-Radushkevich (D-R) models were fitted to equilibrium data. The adsorption process follows kinetic External Film Mass Transfer and Intraparticle Diffusion models, and Freundlich model describes better the system in the equilibrium. It was also verified that the process is spontaneous, endothermic and favorable. D-R model indicated that the adsorption of copper on vermiculite is a physical process.
\end{abstract}

\section{INTRODUCTION}

Generation of industrial wastes has been increasing at growing rates. Among the most dangerous pollutants are those which contain heavy metals and because of that, treatment techniques must be studied and improved. Copper in excessive doses has toxic effects on plants and animals. On plants, the excess alters oxidative activities and some antioxidative processes components (Yruela, 2005). In human beings, it can be retained in brain, liver and pancreas (Davis et al., 2000).

The selected method of heavy metal treatment in this study was the adsorption due to its versatility, allowing the adsorbent choice according to its selectivity towards what it is desired to treat and according to costs and availability.

The alternative adsorbent used in this study was the expanded vermiculite. Vermiculite is a micaceous material with a crystalline structure, which exfoliates by quick losing water. It increases vermiculite volume and decreases its density by a factor of approximately 20 (Machado et al., 2006), to values between 0.05 and $0.30 \mathrm{~g} \mathrm{~cm}^{-3}$. Expanded vermiculite possess a high cation exchange capacity, of the order of $2 \mathrm{meq} / \mathrm{g}$ (Seaborn, 1976), which favors its use as an adsorbent. Stylianou et al. (2006) compared vermiculite and a zeolite (clinoptilolite) as copper adsorbents and vermiculite seemed to be more effective. Nishikawa et al. (2012) evaluated the use of expanded vermiculite on zinc adsorption, verifying that the process is favorable, spontaneous and physical. Malandrino et al. (2006) observed that adsorption of metallic ions on vermiculite decreases with decreasing $\mathrm{pH}$ and with increasing ionic strength. 
Based on the exposed, this work aims to evaluate the use of a Brazilian expanded vermiculite kindly provided by Brasil Minérios LTDA on the removal of copper ions through kinetic and equilibrium studies.

\section{MATERIALS AND METHODS}

\subsection{Kinetic studies}

In kinetic studies, becker flasks containing $1000 \mathrm{~mL}$ of a $1.14 \mathrm{mmol} / \mathrm{L}$ copper solution and $10 \mathrm{~g}$ of expanded vermiculite with an average diameter of $0.855 \mathrm{~mm}$ were used. At previously determined intervals, $4 \mathrm{~mL}$ aliquots were taken and centrifuged. The liquid phases were diluted and their concentrations were determined with atomic absorption spectrometer Perkin Elmer, Analyst 100 model. Each aliquot volume was taken in order to not remove more than $8 \%$ of total volume. Thus, the solution concentration would not be affected by the withdrawn volume.

From Equation 1, metallic ions concentrations were determined at each instant $\mathrm{t}$.

$$
\mathrm{q}(\mathrm{t})=\frac{\mathrm{V}}{\mathrm{m}}\left(\mathrm{C}_{0}-\mathrm{C}(\mathrm{t})\right)
$$

where $\mathrm{C}_{0}$ is the initial metal ion concentration in the solution $(\mathrm{mmol} / \mathrm{L}), \mathrm{C}(\mathrm{t})$ is the metal ion concentration in the solution $(\mathrm{mmol} / \mathrm{L})$ at any time $\mathrm{t}(\mathrm{min}), \mathrm{V}$ is the volume of the solution $(\mathrm{mL})$ and $\mathrm{m}$ is the mass of the dry expanded vermiculite $(\mathrm{g})$.

Equation 2 provides the removal percentage (\%Rem).

$$
\% \operatorname{Re} \mathrm{m}=\left(\frac{\mathrm{C}_{0}-\mathrm{C}_{\mathrm{e}}}{\mathrm{C}_{0}}\right) \cdot 100
$$

where $\mathrm{C}_{\mathrm{e}}$ is the metallic ion concentration in the solution ( $\left.\mathrm{mmol} / \mathrm{L}\right)$ at equilibrium.

The models applied to fit the kinetics curve data may be classified into two main categories according to its mass transfer mechanisms. Pseudo first order model can be expressed by Equation 3 and describes cases in which resistance to mass transfer inside the solid is dominant:

$$
\mathrm{q}=\mathrm{q}_{\mathrm{e}}\left(1-\mathrm{e}^{-\mathrm{k}_{1} \mathrm{t}}\right)
$$

where $\mathrm{q}_{\mathrm{e}}$ is the metal ion concentration in the solid ( $\mathrm{mmol} / \mathrm{g}$ ) at the equilibrium and $\mathrm{k}_{1}$ is the removal kinetic constant $\left(\mathrm{min}^{-1}\right)$.

Pseudo second order model fits cases in which there is a non-linear impelling force. Equation 4 presents pseudo second order model:

$$
\frac{\mathrm{dq}}{\mathrm{dt}}=\mathrm{k}_{2}\left(\mathrm{q}_{\mathrm{e}}-\mathrm{q}\right)^{2}
$$

where $\mathrm{k}_{2}$ is the pseudo second order constant ( $\left.\mathrm{g} / \mathrm{mmol} . \mathrm{min}\right)$. Or, integrating: 


$$
\mathrm{q}=\frac{\mathrm{k} \cdot \mathrm{q}_{\mathrm{e}} \cdot \mathrm{t}}{1+\mathrm{k} \cdot \mathrm{t}}
$$

where $\mathrm{k}=\mathrm{q}_{\mathrm{e}} \cdot \mathrm{k}_{2}$.

When diffusion inside the particle is too slow, determining the limiting step of the process, while diffusion on the surface is instantaneous, the constant intraparticle diffusion rate may be obtained from Equation 6.

$$
q=k_{i} \cdot t^{1 / 2}
$$

The $q v$ s. $t^{1 / 2}$ graph is a straight line which crosses the origin with angular coefficient equal $k_{i}\left(\mathrm{mmol} / \mathrm{g} \cdot \min ^{1 / 2}\right)$. Or, according to Chen et al. (2003), it may show more than one linear region, indicating that more than one step limit the adsorption. First step is the spontaneous adsorption on external surface. Second step is a gradual adsorption when diffusion inside the particle is the limiting step given by Equation 7.

$$
q=k_{i} \cdot t^{1 / 2}+c
$$

The values of $c$ provide an approximation of the boundary layer and the larger the value of c, the larger is the effect of boundary layer. The deviation from a straight line may be attributed to a difference between mass transfer in initial and final adsorption.

Third step is the final equilibrium stage, where diffusion inside the particle starts to decrease due to low adsorbate concentrations in solution (Chen et al., 2003).

The external film mass transfer model considers as limiting step the diffusion from solution to a liquid film adjacent to the particle. The mass transfer rate can be determined by Equation 8.

$$
\frac{\mathrm{dC}}{\mathrm{dt}}=-\mathrm{K}_{\mathrm{TM}}\left[\mathrm{C}(\mathrm{t})-\mathrm{C}_{\mathrm{I}}(\mathrm{t})\right]
$$

where $\mathrm{K}_{\mathrm{TM}}$ is the mass transfer coefficient $\left(\mathrm{min}^{-1}\right), \mathrm{C}_{\mathrm{I}}$ is the solute concentration adjacent to the adsorbent $\left(\mathrm{mg} \mathrm{L}^{-1}\right)$.

The $\mathrm{pH}$ was defined through metallic speciation (approximately 4.5) To adjust $\mathrm{pH}$, it was added when necessary concentrated nitric acid and $\mathrm{pH}$ was measured with an Oakton $\mathrm{pH}$ meter.

\subsection{Adsorption isotherms}

The temperatures tested in equilibrium studies were 293, 313 and $333 \mathrm{~K}$. Erlenmeyer flasks containg $100 \mathrm{~mL}$ of solutions with different copper concentrations and $0.5 \mathrm{~g}$ of expanded vermiculite were kept under constant agitation at a shaker for 5 hours. After the assays, samples were centrifuged and initial and final metallic ion concentrations were determined by atomic absorption. $\mathrm{Cu}\left(\mathrm{NO}_{3}\right)_{2} \cdot 3 \mathrm{H}_{2} \mathrm{O}$ was used to obtain metal ions.

To equilibrium modeling, three models were used: Langmuir, Freundlich and DubininRadushkevich, expressed by Equations from 9 to 11, respectively: 


$$
\mathrm{q}^{*}=\frac{\mathrm{q}_{\max } \cdot \mathrm{b} \cdot \mathrm{C}}{1+\mathrm{b} \cdot \mathrm{C}}
$$

where $\mathrm{q}^{*}$ is the copper concentration in the solid phase $(\mathrm{mmol} / \mathrm{g}), \mathrm{q}_{\max }$ is the maximum quantity of copper removed by gram of adsorbent $(\mathrm{mmol} / \mathrm{g}), \mathrm{b}$ is the ratio between adsorption and removal rates and $\mathrm{C}$ is the copper concentration $(\mathrm{mmol} / \mathrm{L})$.

$$
\mathrm{q}^{*}=\mathrm{a}(\mathrm{C})^{\mathrm{n}}
$$

where a and $\mathrm{n}$ are Freundlich model constants.

$$
\ln \left(\mathrm{q}^{*}\right)=\ln \left(\mathrm{q}_{\mathrm{m}}\right)-\beta \cdot \varepsilon^{2}
$$

where $\mathrm{q}^{*}$ is the amount of metallic ions removed by mass unit of adsorbent $(\mathrm{mg} / \mathrm{g}), \mathrm{q}_{\mathrm{m}}$ is the adsorption capacity of $\mathrm{D}-\mathrm{R}$ model $(\mathrm{mg} / \mathrm{g}), \beta$ is the constant related to adsorption energy $\left(\mathrm{mol}^{2} / \mathrm{J}^{2}\right)$. Parameter $\varepsilon$ is the Polanyi potential, given by:

$$
\varepsilon=\mathrm{RT} \cdot \ln \left(1+\frac{1}{\mathrm{C}}\right)
$$

where $\mathrm{R}$ is the universal gas constant $(\mathrm{J} /(\mathrm{mol} . \mathrm{K}))$ and $\mathrm{T}$ is the temperature $(\mathrm{K})$.

Constant $\beta$ is related to constant $E$ (sorption free energy) and is calculated by:

$$
\mathrm{E}=\frac{1}{\sqrt{2 \beta}}
$$

In very low concentrations, there is linearity between liquid and solid phases known as Henry's Law:

$$
q^{*}=K C
$$

where K os Henry's constant.

Henry's constant is related to enthalpy $(\Delta \mathrm{H})$ and entropy $(\Delta \mathrm{S})$ variations through:

$$
\ln (\mathrm{K})=-\frac{\Delta \mathrm{H}}{\mathrm{RT}}+\frac{\Delta \mathrm{S}}{\mathrm{R}}
$$

Thus, angular coefficient of $\ln \mathrm{K}$ versus $1 / \mathrm{T}$ graph will be $-\Delta H / \mathrm{R}$ and the linear coefficient will be $\Delta \mathrm{S} / \mathrm{R}$. Gibbs free energy $(\Delta \mathrm{G})$ may be calculated from Equation 16 in order to verify the spontaneity of the process.

$$
\Delta G=\Delta H-T \Delta S
$$

\section{RESULTS AND DISCUSSION}

\subsection{Kinetic studies}


Figures 1 and 2 present the adsorption of copper on expanded vermiculite kinetic curves as well as pseudo first order, pseudo second order and intraparticle diffusion models fittings.

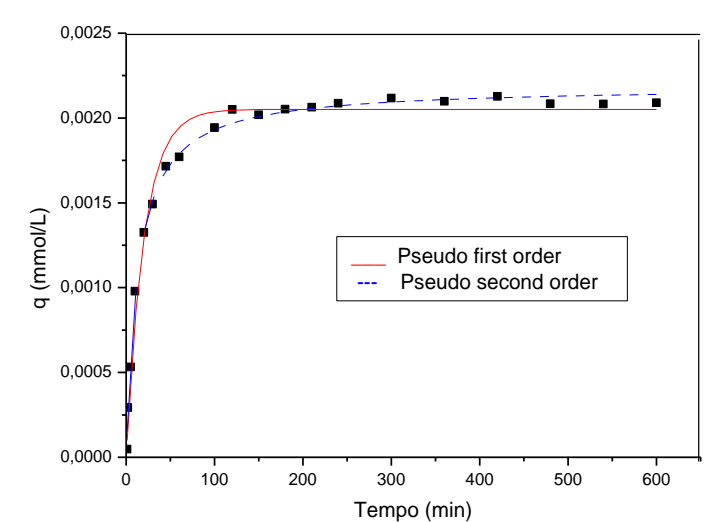

Figure 1 - Kinetic curve of adsorption of copper on vermiculite with pseudo first and pseudo second order models fittings.

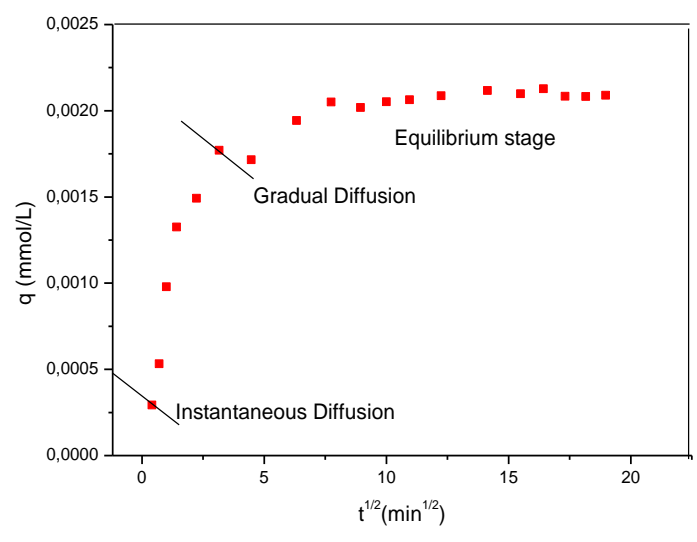

Figure 2 - Intraparticle diffusion curve of adsorption of copper on expanded vermiculite.

From Figure 1 it is possible to note that the system reached equilibrium in approximately 250 minutes, the maximum amount of copper removed was $0.020 \mathrm{mmol}$ of copper/g of vermiculite, which correspond to a removal percentage of $89.13 \%$. Figure 2 shows the intraparticle diffusion adsorption curve, where it is possible to observe the instantaneous diffusion which occurs on the surface, the gradual diffusion stage which takes place inside the particle and the last equilibrium step when diffusion inside the adsorbent decreases due to the low metal ion concentrations in solution. Table 1 lists kinetic parameters obtained from mathematic fittings.

Table 1 - Kinetic parameters of pseudo first order, pseudo second order, intraparticle diffusion and external film adsorption models fittings for the system copper/expanded vermiculite.

\begin{tabular}{|c|c|c|}
\hline \multirow{3}{*}{ Pseudo first order } & $\mathrm{q}_{\mathrm{e}}(\mathrm{mmol} / \mathrm{g})$ & 0.0380 \\
\cline { 2 - 3 } & $\mathrm{k}_{1}\left(\mathrm{~min}^{-1}\right)$ & 0.0715 \\
\cline { 2 - 3 } & $\mathrm{R}^{2}$ & 0.9134 \\
\hline \multirow{3}{*}{ Pseudo second order } & $\mathrm{q}_{\mathrm{e}}(\mathrm{mmol} / \mathrm{g})$ & 0.0398 \\
\cline { 2 - 3 } & $\mathrm{k}_{2}(\mathrm{~g} / \mathrm{mmol} \cdot \mathrm{min})$ & 2.9457 \\
\cline { 2 - 3 } Intraparticle Diffusion & $\mathrm{R}^{2}$ & 0.9684 \\
\cline { 2 - 3 } & $\mathrm{c}(\mathrm{mmol} / \mathrm{g})$ & 0.0041 \\
\cline { 2 - 3 } & $\mathrm{k}_{\mathrm{i}}\left(\mathrm{mmol} / \mathrm{g} \cdot \mathrm{min}^{1 / 2}\right)$ & 0.0051 \\
\hline Mass Transfer in External & $\mathrm{R}^{2}$ & 0.9923 \\
\cline { 2 - 3 } Film & $\mathrm{K}_{\mathrm{TM}}\left(\mathrm{min}^{-1}\right)$ & 0.0033 \\
\hline
\end{tabular}

From Table 1, it can be observed that the External Film Model describes better the system based on its higher regression coefficient. This model considers that the limiting step is the diffusion from the solution to a tiny liquid film formed on the adsorbent particle (Puranik et al., 1999). It may indicate that the operating parameters such as agitation speed could have important effects on the adsorption efficiency. 
Even though external film mass transfer model was the best model for this system, intraparticle diffusion model also presented a satisfying adjustment. In this model, the limiting stage involves mass transfer inside the particle while diffusion on surface is instantaneous. In this case, it would be interesting to investigate the effect of particle size on this adsorption process.

\subsection{Adsorption isotherms}

Figure 3 depicts equilibrium data as well as Langmuir and Freundlich models adjustments at temperatures of 293, 313 and $333 \mathrm{~K}$. Calculated parameters obtained from non-linear and linear regressions are listed in Table 2.

Table 2 - Parameters obtained from adjustment of models to equilibrium data and Henry's constants at low concentrations.

\begin{tabular}{|c|c|c|c|c|c|c|c|c|}
\hline & \multicolumn{3}{|c|}{ Langmuir } & \multicolumn{3}{c|}{ Freundlich } & \multicolumn{2}{c|}{ Henry } \\
\hline $\mathbf{T}(\mathbf{K})$ & $\begin{array}{c}\mathbf{q} \mathbf{m a x} \\
(\mathbf{m m o l} / \mathbf{g})\end{array}$ & $\begin{array}{c}\mathbf{b} \\
(\mathbf{L} / \mathbf{g})\end{array}$ & $\mathbf{R}^{\mathbf{2}}$ & $\begin{array}{c}\mathbf{a} \\
(\mathbf{m m o l} / \mathbf{g})\end{array}$ & $\mathbf{n}$ & $\mathbf{R}^{\mathbf{2}}$ & $\begin{array}{c}\mathbf{k} \\
(\mathbf{L} / \mathbf{g})\end{array}$ & $\mathbf{R}^{\mathbf{2}}$ \\
\hline $\mathbf{2 9 3}$ & 0.26878 & 196.305 & 0.9581 & 0.14872 & 0.40159 & 0.9850 & 1.86201 & 0.9955 \\
\hline $\mathbf{3 1 3}$ & 0.40443 & 210.424 & 0.9775 & 0.22922 & 0.38578 & 0.9881 & 3.22471 & 0.9305 \\
\hline $\mathbf{3 3 3}$ & 0.31437 & 433.984 & 0.9630 & 0.21095 & 0.35724 & 0.9762 & 3.53534 & 0.9838 \\
\hline
\end{tabular}

At all tested temperatures, Freundlich model exhibited regression coefficients closer to the unit, indicating that it is the most adequate model to describe this process. Freundlich model considers adsorption in multilayers, not assuming adsorbent saturation. According to Treybal (1980), in the cases where parameter $n$ is smaller than the unit, adsorption is favorable. Since the highest value found was 0.43521 , it can be concluded that adsorption of copper on expanded vermiculite is a favorable process. El-Bayaa et al. (2009) got similar results for the separation coefficient $\left(\mathrm{K}_{\mathrm{R}}\right)$.

Vieira et al. (2012) carried out a similar study using in natura and calcined rice husks to remove copper from aqueous solutions, obtaining better results whit the calcined samples. It can be observed that in adsorption isotherms, all $\mathrm{q}_{\mathrm{m}}$ obtained in the present study were higher, while in kinetic study the removed amount were little smaller, $0.040 \mathrm{mmol}$ copper/g adsorbent against 0.057 g copper/g adsorbent. In this case, expanded vermiculite advantage resides in the fact that it does not need previous thermal treatment calcination. Abollino et al. (2008) compared the use of vermiculite and montmorillonite as adsorbents of various heavy metals with copper included. The total adsorption capacities provided by breakthrough curves showed that vermiculite presents higher metal uptake amounts than montmorillonite.

Through Henry's constants on Table 2, a graph of $\ln (\mathrm{k})$ versus $1 / \mathrm{T}$ was built and a linear regression was applied. Using Equation 14, it was obtained a $\Delta \mathrm{H}$ of $13.182 \mathrm{~kJ} / \mathrm{mol}$ and the value of $\Delta \mathrm{S}$ was $50.697 \mathrm{~J} /(\mathrm{mol} \mathrm{K})$. Table 3 lists Gibbs free energy calculated through Equation 16.

Negative calculated values of $\Delta \mathrm{G}$ evidence that adsorption on vermiculite is spontaneous and the degree of spontaneity increases with increasing temperature. Higher values of maximum capacity were gotten at higher temperatures, suggesting that this process is of endothermic nature.

Eren and Afsin (2008) investigated raw and acid-activated bentonite as adsorbents of $\mathrm{Cu}(\mathrm{II})$. Raw bentonite presented Gibbs free energy ranging from -0.34 and $-0.71 \mathrm{~kJ} / \mathrm{mol}$ and the acidactivated bentonite showed a variation between -1.13 and $1.49 \mathrm{~kJ} / \mathrm{mol}$. Comparing to the results obtained in this study, with values ranging from -3700.101 to $-658.281 \mathrm{~kJ} / \mathrm{mol}$, it can be concluded that the use of vermiculite results in a process which occurs more easily and spontaneously. 


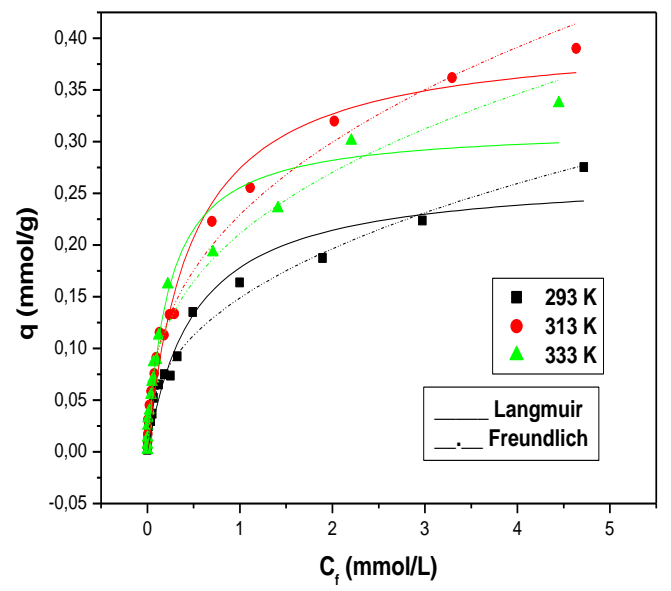

Table 3 - Values of Gibbs free energy calculated.

\begin{tabular}{|c|c|}
\hline Temperature $(\mathbf{K})$ & $\boldsymbol{\Delta G}(\mathbf{k J} / \mathbf{m o l})$ \\
\hline $\mathbf{2 9 3}$ & -658.281 \\
\hline $\mathbf{3 1 3}$ & -2686.161 \\
\hline $\mathbf{3 3 3}$ & -3700.101 \\
\hline
\end{tabular}

Figure 3 - Equilibrium assays at 293, 313 and $333 \mathrm{~K}$ with Langmuir and Freundlich fittings.

Equilibrium data were also adjusted by Dubinin-Radushkevich (D-R) model. Figure 4 illustrates $\ln (\mathrm{q})$ versus $\varepsilon^{2}$ graph and Table 4 presents the constants obtained.

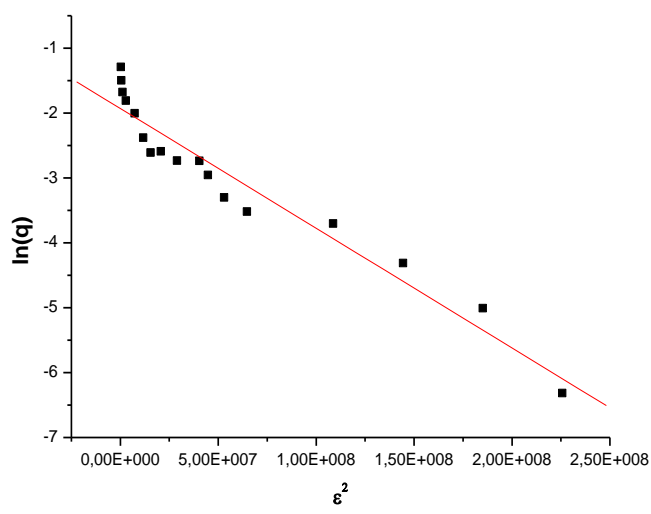

Table 4 - Parameters from D-R model fit.

\begin{tabular}{|c|c|c|c|c|}
\hline $\begin{array}{c}\mathbf{T} \\
(\mathbf{K})\end{array}$ & $\mathbf{q}_{\boldsymbol{m}}$ & $\boldsymbol{\beta}\left(\mathbf{x 1 0}^{\mathbf{8}}\right)$ & $\mathbf{E}(\mathbf{k J})$ & $\mathbf{R}^{2}$ \\
\hline $\mathbf{2 9 3}$ & 0.1390 & 1.8000 & 5.2129 & 0.9683 \\
\hline
\end{tabular}

ure 4 - Linear regression of $\ln (q)$ versus $\varepsilon^{2}$.

Fig

Through Equation 13, energy E was calculated and the value of $5.2129 \mathrm{~kJ}$ indicates a physical adsorption process. According to Kilislioglu and Bilgin (2003), values of E lower than $8 \mathrm{~kJ}$ imply a physical adsorption and values between 8 and $16 \mathrm{~kJ}$ imply a chemical adsorption.

\section{CONCLUSIONS}

In kinetic study, the external film mass transfer and intraparticle diffusion models better fitted the process, indicating that some operating and adsorbent parameters as agitation speed and particle size, may have important effects on adsorption efficiency. The adsorption isotherms were best adjusted by Freundlich model, giving an indicative of a favorable process through the value of parameter n, which was smaller than the unit. Further thermodynamic studies showed that the copper adsorption onto expanded vermiculite is a spontaneous, endothermic and physical process. Finally, the results obtained and the comparisons with previous studies indicate that expanded vemiculite is a promising adsorbent and more studies should be carried out.

\section{ACKNOWLEDGEMENTS}

The authors thank CNPq and CAPES for the financial support. 


\section{REFERENCES}

ABOLLINO, o.; GIACOMINO, A.; MALANDRINO, M.; MENTASTI, E. Interaction of metal ions with montmorillonite and vermiculite. Appl Clay Sci, v.38, p. 227-236, 2008.

CHEN, J. P.; WU, S.; CHONG, K-H. Surface modification of a granular activated carbon by citric acid for enhancement of copper adsorption. Carbon, v.41, p.1979-1986, 2003.

DAVIS, J. A.; VOLESKY, B.; VIERRA, R. H. S. F., Sargassum seaweed as biosorbent for heavy metals. Water Res, v.34, no. 17, p.4270-4278, 2000.

El-BAYAA, A. A.; BADAWY, N. A.; ABD ALKHALIK, E. Effect of ionic strength on the adsorption of copper and chromium ions by vermiculite pure clay mineral. J. Hazard. Mater, v. 170, p. 1204, 2009.

EREN, E.; AFSIN, B. An investigation of $\mathrm{Cu}(\mathrm{II})$ adsorption by raw and acid-activated bentonite: A combined potentiometric, thermodynamic, XRD, IR, DTA study. J. Hazard. Mater, v.151, p.682691, 2008.

KILISLIOGLU, A.; BILGIN, B. Thermodynamic and kinect investigation of uranium adsorption on amberlite IR-118-H resin. Appl Radiat Isotopes., v. 50, p.155-160, 2003.

MACHADO, L. C. R.; TORCHIA, C. B; LAGO, R. M., Floating photocatalysts based on $\mathrm{TiO}_{2}$ supported on high surface area exfoliated vermiculite for water decontamination., Catal. Commun., v.7, p. 538-539, 2006.

MALANDRINO, M., ABOLlinO, O., GIACOMINO, A., ACETO, M., MENTASTI, E., Adsorption of heavy metals on vermiculite: influence of $\mathrm{pH}$ and organic ligands. $J$ Colloid Interf Sci., v.299, p.537-546, 2006.

NISHIKAWA, E.; NETO, A. F. A.; VIEIRA, M. G. A., Equilibrium and Thermodynamic Studies of Zinc Adsorption on Expanded Vemriculite. Adsorpt Sci Technol., v.30, 2012.

PURANIK, P. R.; MODAK, J; M.; PAKNIKAR, K. M., A comparative study of the mass transfer kinetics of metal biosorption by microbial biomass. Hydrometallurgy, v.52, p.189-197, 1999.

SEABORN, D. J.; JAMESON, G. J., Some ion exchange properties of exfoliated vermiculite. Hydrometallurgy, v.2, p.141-155, 1976.

STYLIANOU, M. A.; INGLEZAKIS, V. J.; MOUSTAKAS, K. G.; MALAMIS, S. P.; LOIZIDOU, M. D., Removal of $\mathrm{Cu}$ (II) in fixes bed and batch reactors using natural zeolite and exfoliated vermiculite as adsorbents. Desalination, v.215, p.133-142, 2007.

TREYBAL, R. E. Mass transfer operations. New York: McGraw Hill, 1980.

VIEIRA, M.G.A., ALMEIDA NETO, A. F., SILVA, M. G. C., CARNEIRO, C. N., MELO FILHO, A. A. Characterization and use of in natura and calcined rice husks for biosorption of heavy metals ions from aqueous effluents. Brazilian Journal of Chemical Engineering, v.29, p.619 - 634, 2012.

YRUELA, I., Copper in plants. Braz. J. of Plant Physiol., v. 17, no. 1, 2005. 